Document downloaded from:

http://hdl.handle.net/10251/40401

This paper must be cited as:

Leiva García, R.; Muñoz Portero, MJ.; García Antón, J. (2012). In-Situ Study of Corrosion Evolution of Alloy 926 (UNS N08926) in its Unsensitised and Sensitised State in $\mathrm{LiBr}$ Solutions Using Confocal Laser Scanning Microscopy. ECS Transactions. 41:1-10. doi:10.1149/1.3692434.

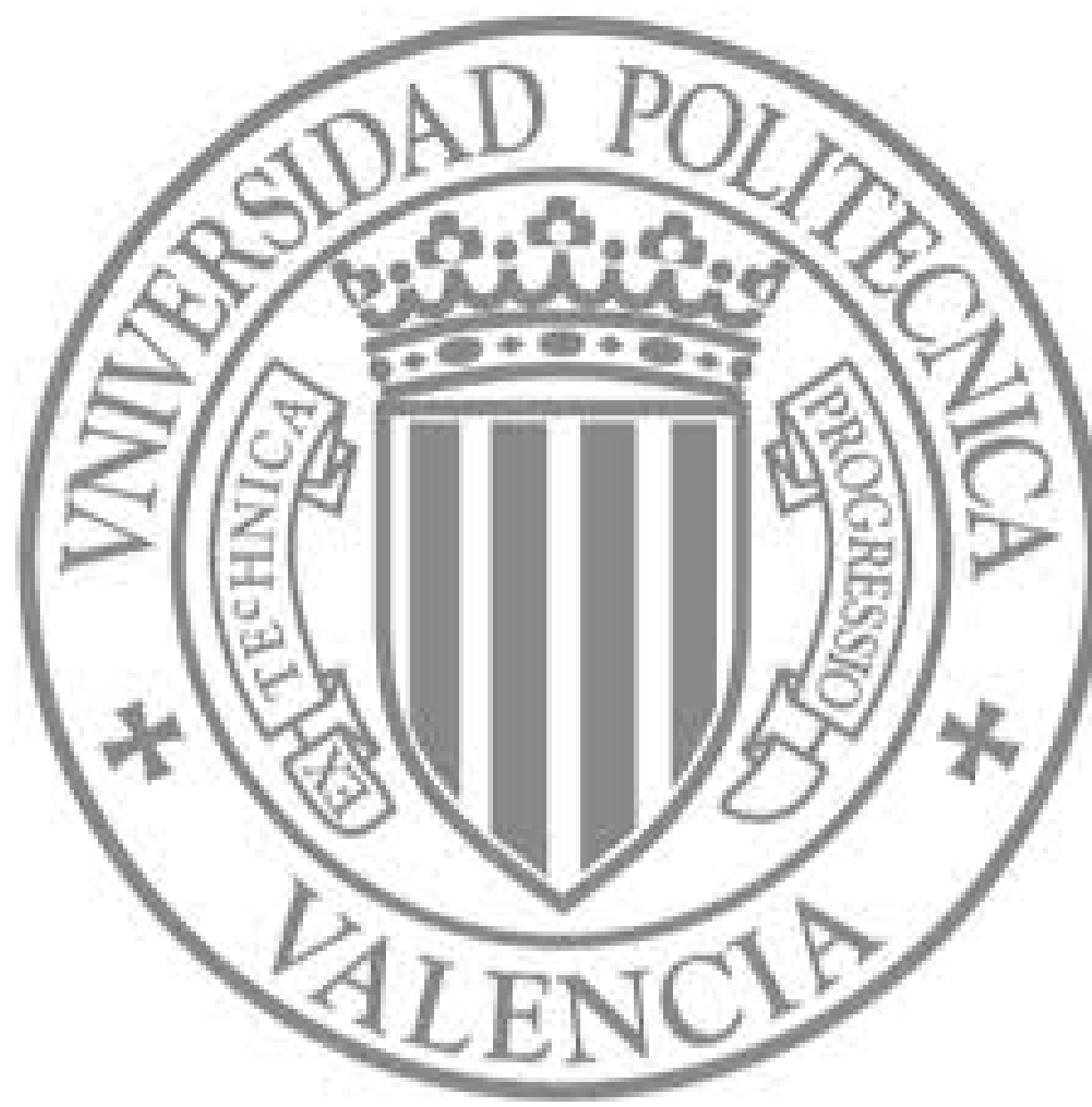

The final publication is available at

http://dx.doi.org/10.1149/1.3692434

Copyright Electrochemical Society 


\title{
In-Situ Study of Corrosion Evolution of Alloy 926 (UNS N08926) in its Unsensitised and Sensitised State in LiBr Solutions Using Confocal Laser Scanning Microscopy
}

\author{
R. Leiva-García, M.J. Muñoz-Portero, J. García-Antón \\ Univ. Politècnica de València, Ingeniería Electroquímica y Corrosión (IEC), Dep. \\ Ingeniería Química y Nuclear, 46022 Valencia, Spain
}

The aim of this work is to study the corrosion evolution of a unsensitised and sensitised stainless steel in a $992 \mathrm{~g} / \mathrm{l} \mathrm{LiBr}$ solution. The tested material has been a highly alloyed austenitic stainless steel (UNS N08926) in its as-received state and heated at $825^{\circ} \mathrm{C}$ for 1 hour in an inert atmosphere. Tests have been carried out in an electrochemical minicell that can be put in the stage of a confocal microscope. Differences in the evolution of morphology attack have been observed between the unsensitised and sensitised samples. The used technique has demonstrated to be very useful to check differences in the evolution of corrosion processes.

\section{Introduction}

Refrigeration absorption machines are again considered as suitable refrigeration systems because the use of chlorofluorocarbons (CFCs) was banned (Montreal Protocol (1), 1987) and their substitutes, i.e. hydrochlorofluorocarbons, are submitted to severe regulations, Kyoto protocol (2), 1997). Absorption machines can use different working fluids, such as $\left(\mathrm{NH}_{3}-\mathrm{H}_{2} \mathrm{O}\right)$ or $\left(\mathrm{H}_{2} \mathrm{O}-\mathrm{LiBr}\right)$. The last one, $\mathrm{H}_{2} \mathrm{O}-\mathrm{LiBr}$, is the most commonly employed refrigerant/absorbent couple in absorption systems due to their favourable thermophysical properties (3). However, $\mathrm{LiBr}$ can cause serious corrosion problems on metallic components in refrigeration systems. Bromides, like chlorides, are aggressive ions and their corrosion effect may be accelerated in absorption machines due to the high temperatures and concentrations reached in them. Therefore, stainless steels are widely used in structural elements because they present good corrosion resistance. The corrosion resistance of stainless steel is mainly due to its chromium content because a chromium oxide film is formed that protects the alloy (4-6). AISI 304 and AISI 316 austenitic stainless steels are the most commonly manufactured materials. However, in austenitic stainless steels, an improper heat treatment in the temperature range between 500 and $900{ }^{\circ} \mathrm{C}$ causes chromium and carbon to react at grain boundaries and form chromium carbides. Concomitant with the formation of chromium, depletion zones appear at the adjacent zones (7-22). Then, the corrosion resistance of the steels decreases as a result of the precipitation of chromium carbides. The high concentration of chromium in $\mathrm{Cr}_{23} \mathrm{C}_{6}$ particles, which is one of the most stable carbides $(23,24)$, reduces locally the chromium content in the region adjacent to these chromium rich precipitates. Since chromium diffuses much more slowly than carbon, there is not enough time for chromium to diffuse to the carbide from all over the grains. So, in the region that is near grain boundaries, the chromium content lowers below $13 \%$, which is a critical value for the corrosion resistance of stainless steels. This process that forms a chromium depletion zone is called sensitisation to intergranular corrosion. 
On the other hand, corrosion has been mainly studied using large-scale experiments (25-28). However, corrosion mechanisms occur on a smaller scale. Then, it can be useful to develop smaller scale methods and experimental methodologies. In this way, it will be possible to study reduced surfaces and the early stages of corrosion processes. Therefore, the aim of this work is the study of the corrosion morphology of a highly alloyed austenitic stainless steel, Alloy 926 (UNS N08926), in its unsensitised and sensitised state in a $992 \mathrm{~g} / \mathrm{l} \mathrm{LiBr}$ solution at microscopic scale.

\section{Experimental procedure}

\subsection{Description of working electrodes}

The material used in this work was a highly alloyed austenitic stainless steel, Alloy 926 (UNS N08926). The Alloy 926 electrodes were machined as shown in Figure 1. These electrodes present a hole in the base, where the electrical connection was made, and a cylindrically reduced bar $1.6 \mathrm{~mm}$ in diameter. Three specimens of Alloy 926 were introduced in a silica tube in a furnace (CARBOLITE TVS 12/600) under an argon atmosphere. Then, the specimens were heated to develop sensitisation. Heat treatments were carried out at $825^{\circ} \mathrm{C}$ for a period of 1 hour. These conditions were selected because in previous works, sensitisation was observed with this heat treatment $(29,30)$. The electrode was covered with an epoxy-resin; in this way only a circular area of $1.6 \mathrm{~mm}$ in diameter was exposed to the $\mathrm{LiBr}$ solution (the area of the electrodes was determined for every test by image analysis). The electrical connection to the potentiostat was done by means of a conductor wire. Prior to the electrochemical tests, the specimens were wet abraded from $220 \mathrm{SiC}$ (Silicon Carbide) grit to a $4000 \mathrm{SiC}$ grit finish, and finally rinsed with distilled water.

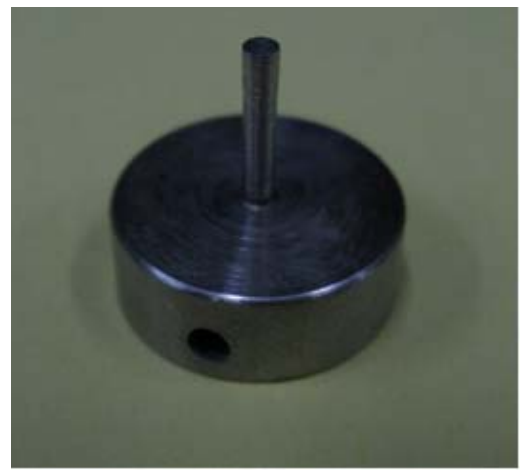

Figure 1. Machined working electrode of Alloy 926.

\subsection{Minicell description}

The minicell, developed in a previous work (31), that was employed in this study permits using confocal laser scanning microscopy in order to observe the beginning of the microscopic corrosion process during the tests. Figure 2 shows a scheme of the minicell. The cell is made of glass and consists of two parts. The first part is a base to support the specimens. This base has four small supports to maintain the working electrode in a horizontal position (Figure $2 \mathrm{c}$ )), and a frosted lateral surface to close the cell with the upper part. The upper part has the inlets and outlets of the cell. There are 
two inlets for the electrodes, the first of them is for the reference electrode, which is a silver-silver chloride with $3 \mathrm{M} \mathrm{KCl}$ reference mini-electrode, and the second inlet serves to take out the electrical connection of the working electrode. The counter electrode consists of two platinum filaments that pass through the glass and are connected outside the cell to the potentiostat. When the cell is closed, it is under a completely insulated atmosphere. Additionally, an inlet and an outlet serve to introduce the electrolyte into the cell from a glass container by means of a pump. The glass container has a thermostatic jacket that controls the temperature of the solution. It is also possible to bubble nitrogen in the solution to deaerate it.

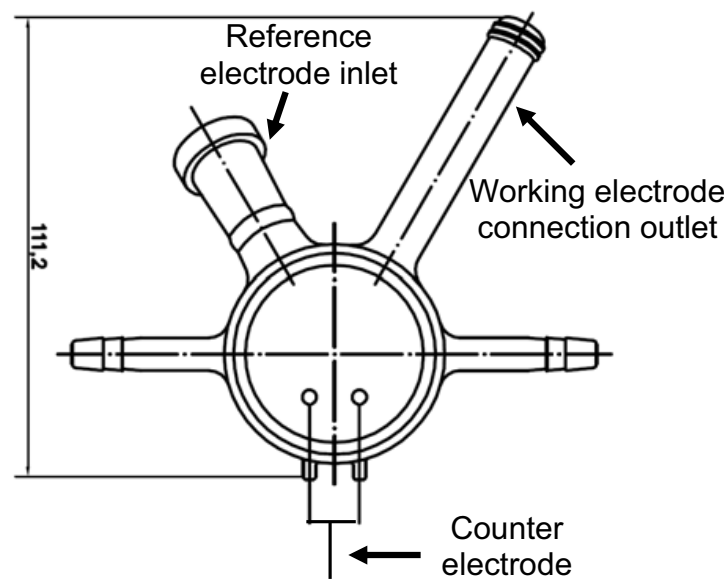

(a)

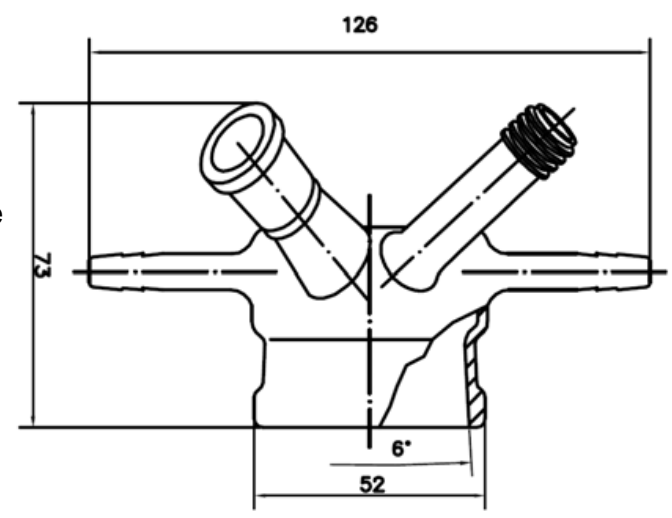

(b)

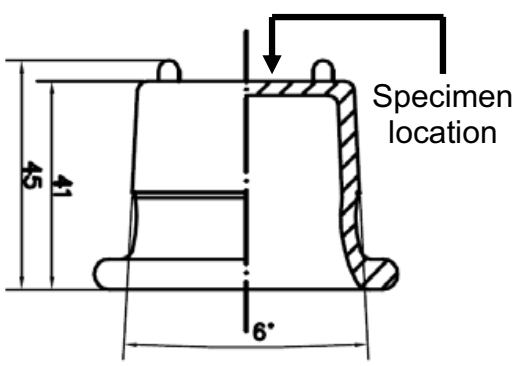

(c)

Figure 2. Scheme of the parts of the minicell: (a) Main view of the top of the cell , (b) Cross view of the top of the cell, and (c) Cross view of the base of the cell (measurements in millimetres).

\subsection{Microscopic systems}

The confocal laser scanning microscope is an "Olympus LEXT 3100 OLS" with the following features:

a) Three acquisition modes: optical light, non-confocal laser, and confocal laser.

b) A motorized stage that permits moving quickly to the interesting region.

c) The change of the objective lens is executed electrically through PC control. 
The confocal laser scanning microscope gives fast, accurate, non-contact measurements of surface topography in three dimensions.

\subsection{Galvanodynamic Curves}

Galvanodynamic curves allow controlling the current, and therefore, it is possible to control the corrosion rate when the damage begins. This point is important because one of the objectives of this work is the study of the first stages and the propagation of the corrosion process; thus, it is very important to control the speed of the process. The tests were repeated at least three times.

Galvanodynamic curves were made in deaireated $992 \mathrm{~g} / \mathrm{l} \mathrm{LiBr}$ aqueous solution by bubbling nitrogen for 15 minutes, prior to immersion. Before each test, the sample was immersed in the test solution for 1 hour at the open circuit potential (OCP). After the OCP test, the specimen's current density was reduced to $0 \mathrm{~mA} / \mathrm{cm}^{2}$ during 60 seconds in order to begin all the tests under the same conditions. Then, the galvanodynamic curves were registered from $0 \mathrm{~mA} / \mathrm{cm}^{2}$ to positive current densities at $10^{-5} \mathrm{~mA} / \mathrm{s}$ sweep rate. Images of the surface of the working electrode were obtained during the tests with the confocal laser scanning microscope.

\section{Results and discussion}

\subsection{Galvanodynamic curves}

Two representative galvanodynamic curves of the sensitised and unsensitised Alloy 926 are shown in Figure 3.

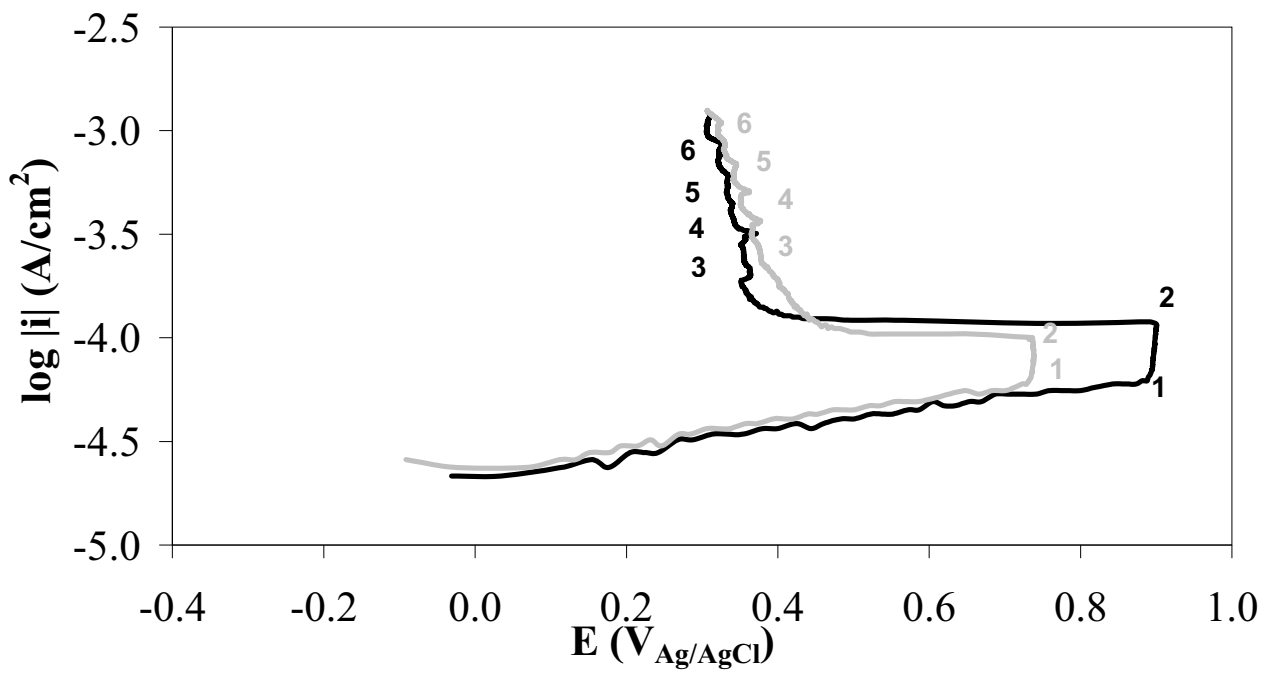

- Unsensitised Alloy 926 - Sensitised Alloy 926

Figure 3. Galvanodynamic curves of unsensitised and sensitised Alloy 926 in the $992 \mathrm{~g} / 1$ $\mathrm{LiBr}$ solution at $25^{\circ} \mathrm{C}$. 
Potential increases with increasing current density in both curves. When current density reaches a certain value the increase of potential is lower and then it decreases quickly; this drop can be related to the pitting potential point. After this potential drop (point 2, Figure 3), some potential peaks, that have been marked with numbers, appear in the galvanodynamic curves at different current density values. As it will be explained later, these potential peaks correspond to the corrosion attack expansion. Table I shows the potential and the current density values of the unsensitised and sensitised Alloy 926 measured at the different points indicated in the galvanodynamic curves.

TABLE I. Potential and current density values of the unsensitised and sensitised Alloy 926 measured at the different points indicated in the galvanodynamic curves.

\begin{tabular}{ccccc}
\hline Point & \multicolumn{2}{c}{ Unsensitised Alloy 926 } & \multicolumn{2}{c}{ Sensitised Alloy $\mathbf{9 2 6}$} \\
& $\mathbf{E}\left(\mathbf{m V}_{\mathbf{A g} / \mathbf{A g} \mathbf{C})}\right.$ & $\mathbf{i}\left(\boldsymbol{\mu} \mathbf{A} / \mathbf{c m}^{2}\right)$ & $\mathbf{E}\left(\mathbf{m V}_{\mathbf{A g} / \mathbf{A g} \mathbf{C l})}\right.$ & $\mathbf{i}\left(\boldsymbol{\mu A} \mathbf{A} / \mathbf{c m}^{2}\right)$ \\
\hline $\mathbf{1}$ & 889 & 71 & 713 & 50 \\
$\mathbf{2}$ & 910 & 104 & 734 & 90 \\
$\mathbf{3}$ & 360 & 169 & 388 & 213 \\
$\mathbf{4}$ & 360 & 389 & 360 & 389 \\
$\mathbf{5}$ & 350 & 489 & 350 & 537 \\
$\mathbf{6}$ & 340 & 691 & 340 & 724 \\
\hline
\end{tabular}

The drop in the potential happens at lower potential values for the sensitised sample than for the unsensitised sample. Furthermore, the pitting current density (point 2) in the sensitised sample is lower than in the unsensitised sample. Therefore, the corrosion resistance is lower as a consequence of the sensitisation process. On the other hand, the current density value is similar to the value proposed in the literature to establish the pitting potential $\left(100 \mu \mathrm{A} / \mathrm{cm}^{2}\right)(32)$.

\subsection{Analysis with the confocal laser scanning microscope}

Figures 4 and 5 show optical images of the evolution of the corrosion damage during the galvanodynamic curves carried out with the unsensitised and sensitised Alloy 926 in the $992 \mathrm{~g} / 1 \mathrm{LiBr}$ solution at $25^{\circ} \mathrm{C}$. Figures 4 a) and 5 a) show how the corrosion product spread out the affected area and corrosion attack mainly affects the centre of this volume. Corrosion goes on spreading from the centre of the circle, until it gets to the limit of the circle as shown in Figures $4 \mathrm{~b}$ ) and $5 \mathrm{~b}$ ). Then, the corrosion product expands and the circle grows, Figures $4 \mathrm{c}$ ) and $5 \mathrm{c}$ ), and corrosion goes on expanding again until it arrives at the end of the new circle (Figure $4 \mathrm{~d}$ ) and $5 \mathrm{~d}$ )). This sequence (corrosion product expansion, corrosion attack growth inside the corrosion product, and again corrosion product expansion) happens over and over again. Therefore, corrosion spreads affecting the entire surface in a sequential way with increasing current density in the galvanodynamic curve. It seems that the corrosion products catalyze the subsequent corrosion processes, this behaviour being according to the literature (33-37). Every time that the corrosion product forms a new circle and corrosion begins to affect a greater area of the electrode, a potential peak appears in the galvanodynamic curves (peaks are marked with numbers from 3 to 6 for both samples in Figure 3).

On the other hand, there are clear differences in the corrosion attack between the unsensitised and sensitised Alloy 926. In the case of the unsensitised Alloy 926, pits appear in a random way inside the cloud of corrosion product, while in the sensitised Alloy 926, corrosion grows along the grain boundaries that are inside the cloud of 
corrosion product. These differences in the morphology of corrosion attack are due to chromium carbide precipitation in the sensitised sample. Areas depleted of alloying elements (Cr, Mo) appear surrounding chromium carbides (7-22) and these areas are preferential zones for corrosion attack. In the sensitised samples corrosion attack grows along these areas that are in the grain boundaries.

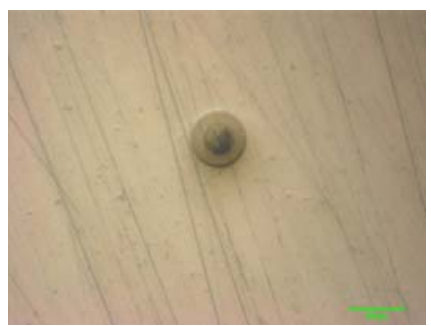

a)

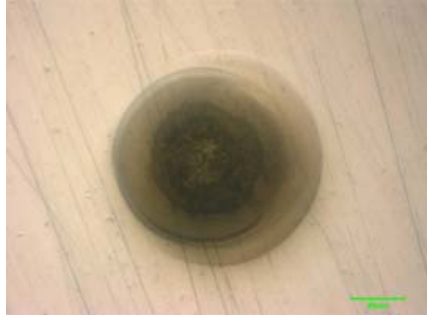

d)

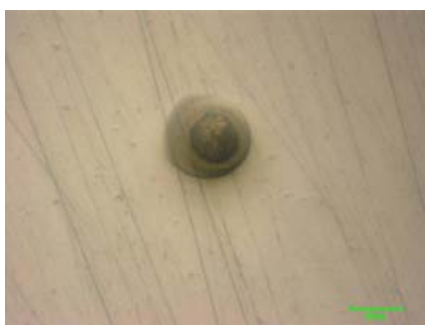

b)

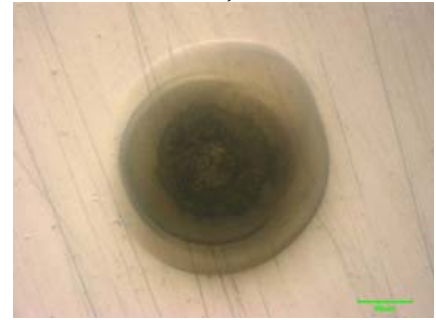

e)

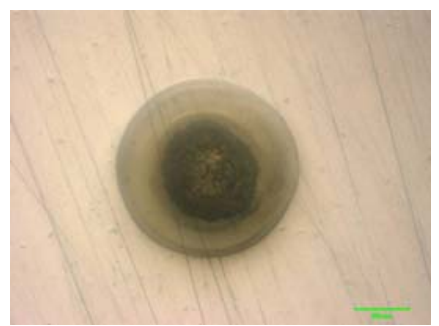

c)

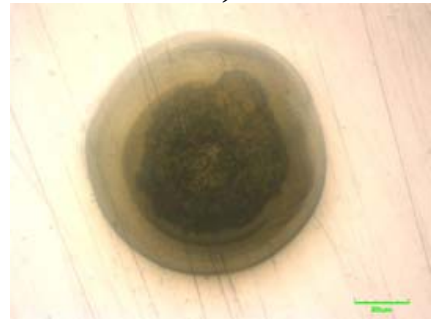

f)

Figure 4. Optical images of corrosion damage evolution in the unsensitised Alloy 926 during a galvanodynamic curve in the $992 \mathrm{~g} / 1 \mathrm{LiBr}$ solution at $25^{\circ} \mathrm{C}$ obtained by means of the CLSM.

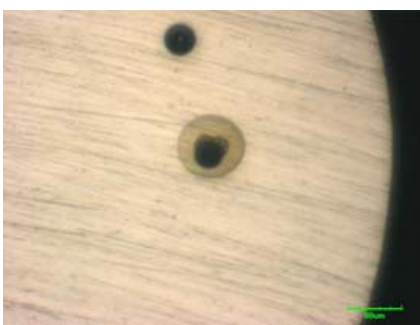

a)

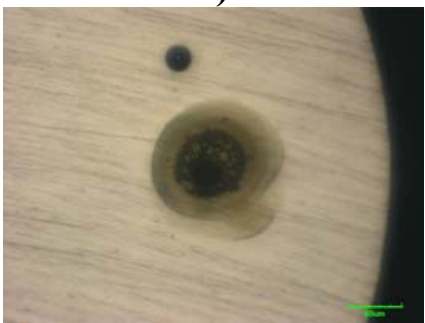

d)

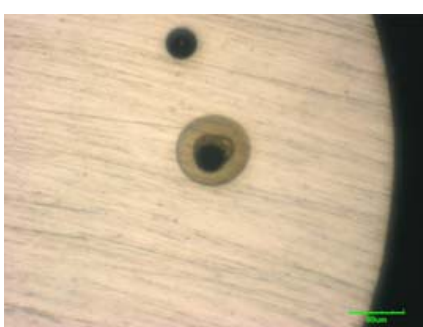

b)

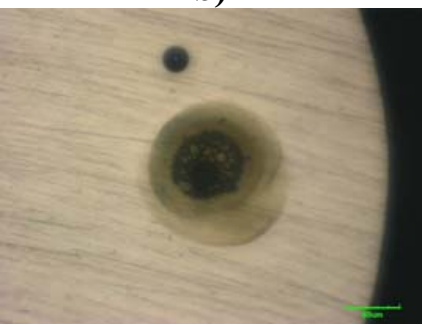

f)

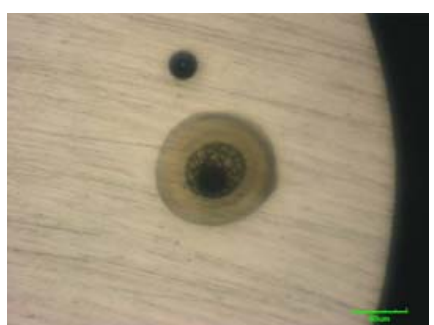

c)

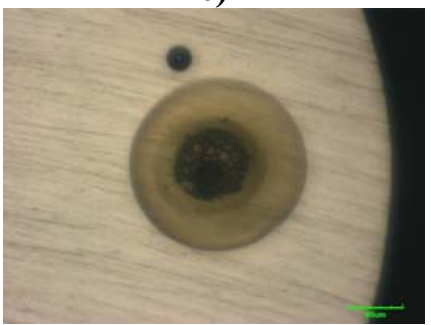

e)

Figure 5. Optical images of corrosion damage evolution in the sensitised Alloy 926 during a galvanodynamic curve in the $992 \mathrm{~g} / \mathrm{LiBr}$ solution at $25^{\circ} \mathrm{C}$ obtained by means of the CLSM. 
Values of the area affected by corrosion and current values were obtained for every point of the galvanodynamic curve marked in Figure 3. Despite the fact that current density is calculated over the entire surface, all the current flows through the area affected by corrosion. Therefore, the effective current density that affects the attacked area was calculated. These values are summarised in Table II. On the other hand, Figure 6 shows the evolution of the affected area and the effective current density during the test for both samples.

Table II. Values of the effective current density, and damage extension at the different points marked in the galvanodynamic curves of the unsensitised and sensitised Alloy 926 in the $992 \mathrm{~g} / 1 \mathrm{Libr}$ solution at $25^{\circ} \mathrm{C}$.

\begin{tabular}{|c|c|c|c|c|}
\hline \multirow[t]{2}{*}{ Point } & \multicolumn{2}{|c|}{ Unsensitised Alloy 926} & \multicolumn{2}{|c|}{ Sensitised Alloy 926} \\
\hline & $\begin{array}{r}\text { Effective current } \\
\text { density }\left(\mu \mathrm{A} / \mathrm{cm}^{2}\right)\end{array}$ & $\begin{array}{c}\text { Affected area } \\
\left(\mu \mathrm{m}^{2}\right)\end{array}$ & $\begin{array}{r}\text { Effective current } \\
\text { density }\left(\mu \mathrm{A} / \mathrm{cm}^{2}\right)\end{array}$ & $\begin{array}{c}\text { Affected area } \\
\left(\mu \mathrm{m}^{2}\right)\end{array}$ \\
\hline 1 & $3.8 \times 10^{7}$ & 4.0 & $2.7 \times 10^{7}$ & 4.0 \\
\hline 2 & $3.9 \times 10^{4}$ & $5.3 \times 10^{3}$ & $3.4 \times 10^{4}$ & $6.5 \times 10^{3}$ \\
\hline 3 & $4.1 \times 10^{4}$ & $8.7 \times 10^{3}$ & $1.8 \times 10^{4}$ & $9.1 \times 10^{3}$ \\
\hline 4 & $1.4 \times 10^{4}$ & $5.7 \times 10^{4}$ & $1.4 \times 10^{4}$ & $5.9 \times 10^{4}$ \\
\hline 5 & $1.2 \times 10^{4}$ & $9.5 \times 10^{4}$ & $1.0 \times 10^{4}$ & $1.1 \times 10^{5}$ \\
\hline 6 & $4.6 \times 10^{3}$ & $3.2 \times 10^{5}$ & $4.2 \times 10^{3}$ & $3.9 \times 10^{5}$ \\
\hline
\end{tabular}

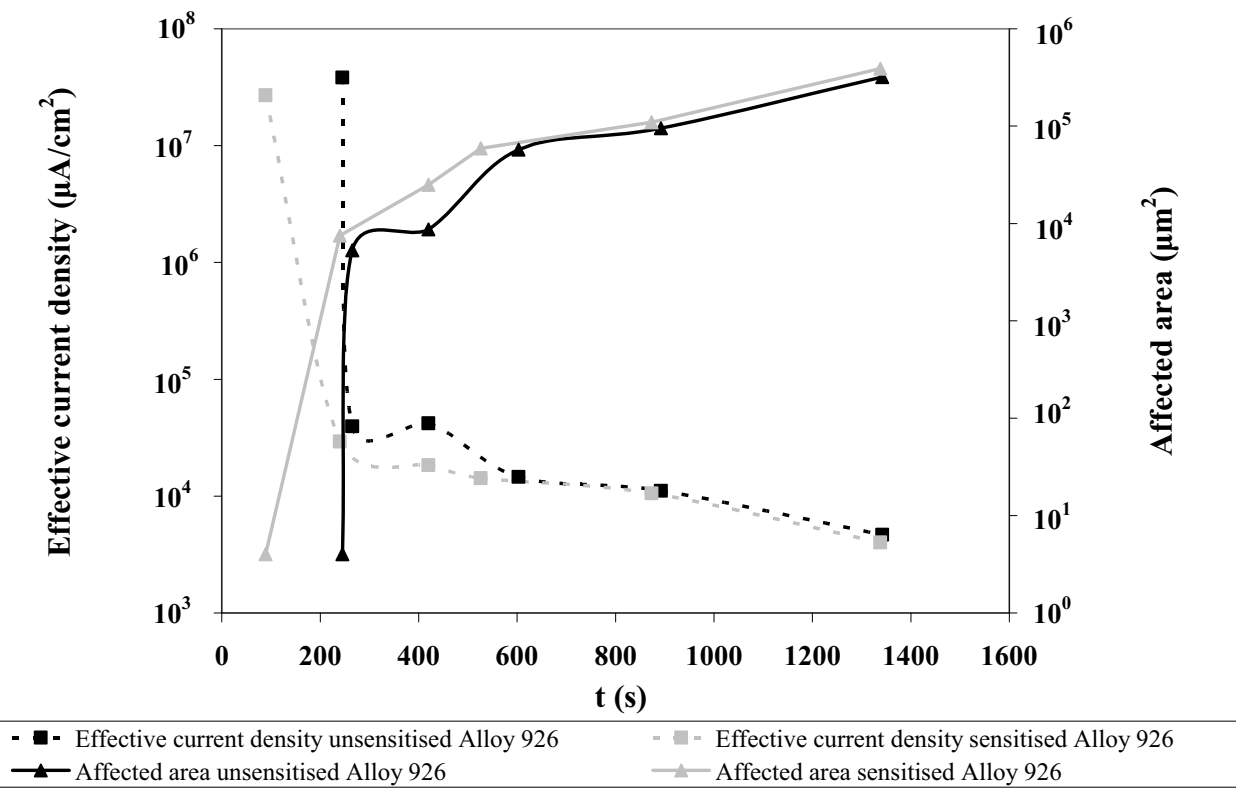

Figure 6. Effective current density and evolution of the damage area during the galvanodynamic tests for the unsensitised and sensitised Alloy 926 in the $992 \mathrm{~g} / \mathrm{l} \mathrm{LiBr}$ solution at $25^{\circ} \mathrm{C}$.

The effective current density that passes through the affected area is high at the beginning of the damage and then it decreases quickly with the growth of the affected area (38). The effective current density that flows at the beginning of pit formation is very high in both samples $\left(38 \mathrm{~A} / \mathrm{cm}^{2}\right.$ for the unsensitised Alloy 926 and $27 \mathrm{~A} / \mathrm{cm}^{2}$ for the sensitised sample) because the affected area is very small $\left(4 \mu \mathrm{m}^{2}\right)$. Therefore, the beginning of the corrosion processes is very fast and the affected area grows quickly 
during the first stages of the attack. In addition, the affected area /unaffected area ratio is very unfavourable to the pit. The greater the affected area is the more slowly the corrosion product spreads, and the time intervals among peaks in the galvanodynamic curves increase.

Regarding the differences between both specimens, when the pit appears the effective current density in the case of the sensitised sample is lower than in the case of the unsensitised Alloy 926. Therefore, the corrosion resistance of the sensitised sample is lower than in that of the unsensitised Alloy 926. Similarly, the affected area is slightly larger in the case of the sensitised sample.

Finally, Figure 7 shows two three-dimensional images of the unsensitised and sensitised Alloy 926 after the galvanodynamic curves in the $992 \mathrm{~g} / 1 \mathrm{Libr}$ solution at $25^{\circ} \mathrm{C}$. The differences in morphology attack between the unsensitised and sensitized Alloy 926 are confirmed in the images obtained after the galvanodynamic tests. In the case of the unsensitised Alloy 926, different pits occur randomly along the affected area. However, in the case of the sensitised sample, all grain boundaries inside the affected area are attacked and deep ditches appear on the surface. The attack goes on spreading from these areas to the rest of the surface.

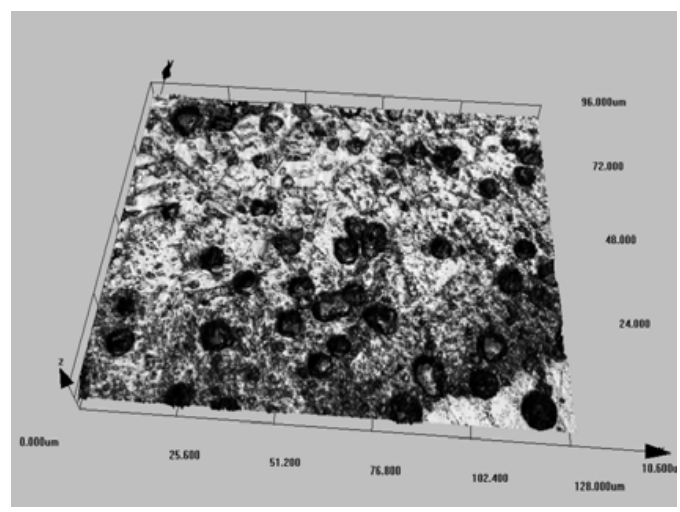

a) Unsensitised Alloy 926

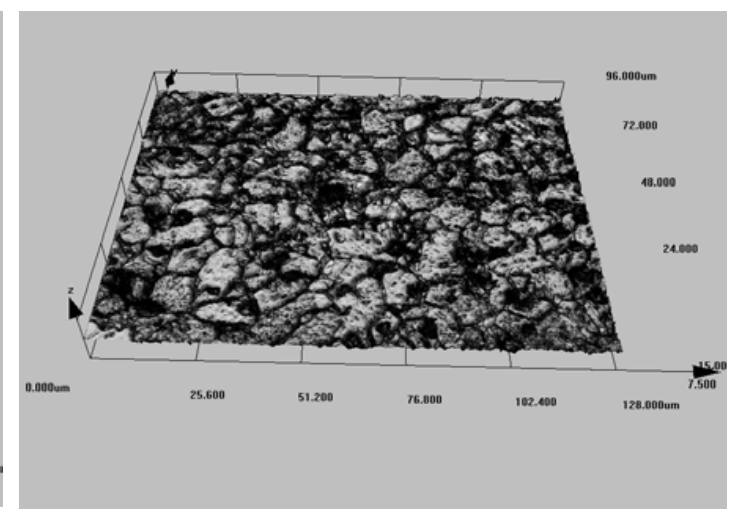

b) Sensitised Alloy 926

Figure 7. 3D images of the electrode surface of the unsensitised and sensitised Alloy 926 after galvanodynamic curves in the $992 \mathrm{~g} / \mathrm{LiBr}$ solution at $25^{\circ} \mathrm{C}$.

\section{Conclusions}

The main conclusions of this work can be summarised as follows:

1. Sensitised Alloy 926 is less corrosion resistant than unsensitised Alloy 926.

2. The corrosion process is sequential: first the corrosion damage appears, next the corrosion product spreads, and finally the corrosion damage starts growing again.

3. Corrosion product catalyses the corrosion attacks.

4. The effective current density is very high in the formation of the initial pit.

5. Pits appear in a random way in the unsensitised Alloy 926 whereas corrosion grows along grain boundaries in the sensitised Alloy 926. 


\section{Acknowledgments}

We wish to express our gratitude to MICINN (CTQ2009-07518), to Universitat Politècnica de València (CEI-01-11), to Generalitat Valenciana (for its help in the CLSM acquisition (MY08/ISIRM/S/100), to Dr. Helena Alves from Krupp VDM for supplying the materials, and to Dr. Asunción Jaime for her translation assistance.

\section{References}

1. Council Decision of 14 October 1988 concerning the conclusion of the Vienna Convention for the protection of the ozone layer and the Montreal Protocol on substances that deplete the ozone layer, Official Journal L 297, 31/10/1988 p. 828.

2. http://unfccc.int, website of United Nations Framework Convention on Climate Change. 2010).

3. K. Tanno, M. Itoh, T. Takahashi, H. Yashiro, and N. Kumagai. Corros. Sci., 34 1441 (1993).

4. Y.F.Cheng, J. L. Luo. Electrochim. Acta 44, 4795 (1999).

5. Jae-Bong Lee. Mater. Chem. Phys. 99, 224 (2006).

6. M.J.Carmezim, A. M. Simoes, M. F. Montemor, and M. D. Belo. Corros. Sci. 47, 581 (2005).

7. M. Matula, Z. Stonawska, L. Tuma, C. Dagbert, L. Hyspecka, and J. Galland. Electrochemical testing of sensitization to intergranular corrosion in stainless steel. Eurocorr 2001 . 2001.

8. O. Greven, H.-E Bühler, and L.Gerlach. Corrosion investigations on chemical resistant steels by means of the potenciostatic electrochemical reactivation test (ERT). Eurocorr 2001 . 2001.

9. V. Kain, R.C. Prasad, and P.K. De. Corrosion 58, 15 (2002).

10. Z. Fang, Y.S. Wu, L. Zhang, and J.Q. Li. Corrosion 54, 339 (1998).

11. P. Muraleedharan, J.B. Gnanamoorthy, and P. Rodriguez. Corrosion 52, 790 (1996).

12. M. Matula, L. Hyspecka, M. Svoboda, V. Vodarek, C. Dagbert, J. Galland, Z. Stonawska, and L. Tuma. Matherials characterization 46, 203 (2001).

13. H.-E Bühler, L. Gerlach, O. Greven, and W. Bleck. Corros. Sci. 45, 2325 (2003).

14. S. Zhang, T. Shibata, and T. Haruna. Corros. Sci. 47, 1049 (2005).

15. AnKe Hempsch, G.Schmitt, and W.Blek. Advances in assessing the susceptibility to intergranular corrosion (IGC) of duplex stainless steel using the electrochemical reactivation test (ERT). Eurocorr 2006, (2006).

16. G.H. Aydogdu and M.K. Aydinol. Corros. Sci. 48, 3565 (2006).

17. H. Shaikh, N. Sivaibharasi, B. Sasi, T. Anita, R. Amirthalingam, B.P.C. Rao, T. Jayakumar, H.S. Khatak, and B. Raj. Corros. Sci. 48, 1462 (2006).

18. V.Kain, K.Chandra, K.N.Adhe, and P.K.De. Corrosion 61, 587 (2005).

19. A.S. Lima, A.M. Nascimento, H.F.G. Abreu, and P. Lima-Neto. J. Mat. Sci. 40, 139 (2005).

20. T. Amadou, C. Brahan, and H. Sidhom. Metall. Mater. Trans. A-Phys. Metall. Mater. Sci. 35A, 3499 (2004).

21. N. Parvathavarthini, R. K. Dayal. J. Nucl. Mat. 399, 62 (2010). 
22. X. Yu, S. Chen, Y. Liu, F. Ren. Corros. Sci. 52, 1939 (2010).

23. K.O.E. Henriksson, N. Sandberg, and J. Wallenius. Appl. Phys. Lett. 93, 191912 (2008).

24. M.Detroye, F. Reniers C. Buess-Herman J. Vereecken. Appl. Surf. Sci. 144-145, 78 (1999).

25. Z. Szklarska-Smialowska. Pitting corrosion of metals. NACE international publishers . (1986). Houston.

26. Wen-Ta Sai, Chi-Lu Yu, and Jeih-Ing Lee. Scripta Mater. 53, 505 (2005).

27. S.E. Lott and R.C. Alkire. J. Electrochem. Soc. 136, 973 (1989).

28. E. Blasco Tamarit, A. Igual, J. García-Antón. Corros. Sci. 50, 1848 (2008).

29. R. Leiva-Garcia, M.J. Muñoz-Portero, and J. García-Antón. Corros. Sci. 51, 2080 (2009).

30. R. Leiva-Garcia, M.J. Muñoz-Portero, and J. Garcia-Anton. Comparative study of electrochemical methods and image analysis for the characterization of Alloy 146, 279, 900, and 926 sensitization to intergranular corrosion. Eurocorr 2008. (2008).

31. R. Leiva-García, J. García-Antón, and M. J. Muñoz-Portero. Corros. Sci. 52, 2133 (2010).

32. M. Kaneko and H. S. Isaacs, Corros. Sci. 42, 67 (2000).

33. B. Wu, J.R. Scully, J.L. Hudson, and A.S. Mikhailov. J Electrochem Soc. 144, 1614 (1997).

34. A. S. Mikhailov, J. R. Scully, and J. L. Hudson, Surf. Sci. 603, 1912 (2009).

35. C. Punckt, M. Bolscher, H. H. Rotermund, A. S. Mikhailov, L. Organ, N. Budiansky, J. R. Scully, and J. L. Hudson. Science 305, 1133 (2004).

36. M. Dornhege, C. Punckt, J.L. Hudson, and H.R. Rotermund. J. Electrochem. Soc. 154, C24 (2007).

37. T.T.Lunt, V. Brusamarello J. R. Scully J. L. Hudson. Electrochem. Solid State Lett. 3, 271 (2000).

38. J. García Antón, A. Igual Muñoz, J.L. Guiñón, and V. Pérez Herranz. J. Appl. Electrochem. 31, 1195 (2001). 